\title{
THE EFFECTS OF OFFSHORE ASSEMBLY ON INDUSTRY LOCATION: EVIDENCE FROM U.S. BORDER CITIES
}

Gordon H. Hanson

Working Paper 5400

\section{NATIONAL BUREAU OF ECONOMIC RESEARCH 1050 Massachusetts Avenue Cambridge, MA 02138 \\ December 1995}

Prepared for the NBER Conference, "Effects of U.S. Trade Protection and Promotion Policies," Richmond, VA, October 6-7, 1995. I thank Jim Harrigan and conference participants for comments. Raymond Robertson provided excellent research assistance. This paper is part of NBER's research program in International Trade and Investment. Any opinions expressed are those of the author and not those of the National Bureau of Economic Research.

(C) 1995 by Gordon H. Hanson. All rights reserved. Short sections of text, not to exceed two paragraphs, may be quoted without explicit permission provided that full credit, including (C) notice, is given to the source. 


\title{
THE EFFECTS OF OFFSHORE \\ ASSEMBLY ON INDUSTRY LOCATION: \\ EVIDENCE FROM U.S. BORDER CITIES
}

\begin{abstract}
In this paper, I examine how the growth of offshore assembly in Mexico has affected manufacturing activity in U.S. border cities. Under the offshore assembly provision of the U.S. tariff schedule, goods that are assembled abroad using U.S.-manufactured components receive preferential tariff treatment upon reentry into the United States. Foreign assembly plants in Mexico, most of which are owned by U.S.-based multinationals, are overwhelmingly concentrated along the border with the United States. I combine data on employment and earnings in twodigit manufacturing industries for U.S. border cities with data on employment and value added in foreign assembly plants in the corresponding Mexican border cities. I study the effect that the expansion of offshore assembly in a Mexican border city has on durable and nondurable manufacturing activities in the neighboring U.S. border city. The estimation results show strong support for the hypothesis that the growth of export assembly in Mexico increases the demand for manufacturing goods produced in U.S. border cities. Implications of the North American Free Trade Agreement for the U.S.-Mexico border region are discussed.
\end{abstract}

Gordon H. Hanson

Department of Economics

University of Texas

Austin, TX 78712

and NBER 


\section{Introduction}

One of the principal arguments presented against the North American Free Trade Agreement (NAFTA) was that it would encourage domestic manufacturers to shut down their operations in the United States and move them to Mexico. The NAFTA debate was by no means the first time labor unions and other protectionist interests had appealed to such concerns in an attempt to restrict trade between the United States and low-wage countries. The offshore assembly provision (OAP) of the U.S. tariff code has been the focus of repeated debates, with labor consistently arguing for its repeal. ${ }^{!}$

An OAP permits the duty-free return of domestically-manufactured components that have been processed in another country. The importing agent is required to pay import duties only on the value added abroad. OAPs do reduce the cost of moving assembly operations abroad -hence the source of labor opposition -- but this is by no means the sole impact of offshore assembly on the domestic economy..: The existence of transport costs gives domestic components manufacturers an incentive to locate near the foreign assembly plants they supply. If a U.S. producer supplies assembly plants in a particular foreign region, the firm, all else equal, has an incentive to locate its production operations in the U.S. port city or border area that offers the least-cost access to the foreign market. An OAP, then, potentially affects not only the international location of assembly but also the internal location of complementary manufacturing activities in the source country. ${ }^{2}$

\footnotetext{
1 See Grunwald and Flamm (1985), Schoepfle and Perez-Lopez (1988), and Mendez (1993) for a discussion of labor union opposition to the U.S. OAP.

2 This possibility may explain labor's coolness towards the argument that an OAP prevents the United States from losing entire industries -- components production and assembly -- to foreign countries. For a union, there is little difference between a components firm moving to Asia and it moving to a right-to-work state such as Texas.
} 
In this paper, I study the impact of offshore assembly on the location of manufacturing activity in the United States. The locational effects of OAPs have yet to be addressed in the literature. Grossman (1982) develops a theoretical framework that identifies the conditions under which an OAP offers greater protection than a conventional pure-tariff scheme. Finger (1976), Mendez, Murray, and Rousslang (1991), and Mendez (1993) examine the welfare effects of OAPs. All three studies find that, compared to a flat-rate tariff scheme, the U.S. OAP offers a slight to moderate improvement in welfare and redistributes income from domestic assemblers to components producers and consumers. One shortcoming of these analyses is that they aggregate over regions within a country. To the extent that an OAP causes components production in the source country to internally relocate, it may generate interregional distributional effects that are missed at the national level.

An additional motivation for studying the U.S. OAP is that it offers a preview of the effects that NAFTA is likely to have on industry location in the United States. ${ }^{3}$ Mexico is one of the largest suppliers of OAP imports to the U.S. economy. Given Mexico's proximity to the United States and its relatively abundant supply of low-wage labor, the country is a natural site in which to locate offshore assembly for the U.S. market. There is little reason to believe that NAFTA will change the current binational pattern of specialization in manufacturing. In the absence of trade barriers, it is likely that the United States will have a comparative advantage in components production and Mexico will have a comparative advantage in assembly operations. To the extent transport costs matter for industry location, the U.S.-Mexico border region is likely

\footnotetext{
${ }^{3}$ There have been numerous studies on how NAFTA will affect welfare and resource allocation in the United States, Canada, and Mexico (see Brown, Deardorff, and Stern (1992) for a survey). Only Henderson (1993) addresses the intra-national locational consequences of economic integration.
} 
to become an important production site for the integrated North American market.

The approach I take is to study how the growth of offshore assembly in Mexico has affected the U.S. border economy. I construct a data set on manufacturing activities in U.S. and Mexican border cities using a combination of U.S. and Mexican government sources. The cities on the U.S.-Mexico border form, in many respects, binational metropolitan areas. City pairs such as San Diego-Tijuana and El Paso-Ciudad Juarez are divided by an international boundary, but they engage in extensive trade in goods and labor services. It is in the larger Mexican border cities that most offshore assembly for the U.S. market occurs. This makes U.S. border cities a natural site in which to locate complementary manufacturing activities. The particular question I ask is whether the growth of export assembly plants in Mexican border cities has contributed to the expansion of specific manufacturing activities in neighboring U.S. border cities.

The body of the paper has five sections. Section $I$ discusses U.S. and Mexican trade policies regarding offshore assembly. Section III describes manufacturing activities in the U.S.Mexico border region. Section IV presents empirical results. Section V concludes.

\section{Offshore Assembly and U.S.-Mexico Trade}

There are two categories of goods that qualify for the U.S. OAP. Item 9802.00 .60 of the Harmonized Tariff Schedule (HTS) of the United States (formerly item 806.30 of the Tariff Schedule of the United States (TSUS)) permits the duty-free import of metal products that are

\footnotetext{
4 Hanson (1995) examines the effect of U.S.-Mexico integration on the overall pattern of economic activity in the U.S. border region.
} 
manufactured in the United States and sent abroad for further processing. ${ }^{5}$ Item 9802.00 .80 of the HTS (formerly item 807.00 of the TSUS) permits the duty-free entry of inputs that are manufactured in the United States and assembled abroad. ${ }^{6}$ To qualify for the 9802.00 .80 exemption, the stated requirements are that domestic components may only be subject to assembly and assembly-related activities abroad. Goods imported under item 9802.00 .80 account for over 98 percent of total OAP imports in any given year.

Figure 1 shows total U.S. OAP imports in levels and as a share of total U.S. imports for the period 1970-1990. Between 1980 and 1990, the share of OAP imports in total imports increased from $4.7 \%$ to $12.2 \% .^{7}$ OAP imports are concentrated in three product groups: motor vehicles and motor vehicle parts, electronics, and apparel. Table 1 shows the share of selected products in total U.S. OAP imports, total dutiable U.S. OAP imports, and total duty-free U.S. OAP imports over the period 1980-1990. Duty-free OAP imports represent the value of the final product that is attributable to U.S.-manufactured parts and components; dutiable OAP imports represent value added abroad. Machinery and equipment, in total, accounted for $88.6 \%$ to $92.3 \%$

5 TSUS item 806.30 incorporated into the tariff code a provision of the Tariff Act of 1930. While the provision was intended to facilitate the manufacturing practices of U.S. steel firms that maintained operations in Canada, there was no apparent desire on the part of the Congress to limit the provision to contiguous countries (USITC 1988b).

6 Item 807.00 was created in 1963 by the U.S. Tariff Commission. It codified into law a 1954 decision by the U.S. Customs Court regarding customs practices established under the Tariff Act of 1930 (USITC 1988b).

TAP imports show a large increase between 1986 and 1987 . This is partly the result of firms reclassifying their imports under the OAP in order to avoid paying a custom user fee, which was introduced in December, 1986 (USITC 1988b). There are several tariff provisions that allow firms to import goods duty free, including the Generalized System of Preferences (GSP), the Caribbean Basin Economic Recovery Act (CBERA), the Automotive Products Trade Act (APTA), the Civil Aircraft Agreement, and the U.S.-Israel Free Trade Agreement. In addition, certain goods have a free duty rate under the most-favored-nation (MFN) clause. Firms entering imports under these provisions had until 1986 no incentive to also enter their goods under the OAP. With the imposition of a $0.22 \%$ ad valorem custom user fee in December 1986, many firms (except those using the GSP or CBERA, which are precluded from using the OAP) have begun entering their imports under the OAP to take advantage of the fact that both the dutiable and duty-free portions of OAP imports are exempt from the user fee (USITC 1988b). 
of total OAP imports over the period. Motor vehicles are the single largest category of OAP imports, accounting for $59.1 \%$ of total OAP imports in 1990 . The next largest categories are electronic items, including semiconductors and office machines, followed by apparel.

There is considerable variation across products in the U.S. content of OAP imports. Table 2 shows duty-free OAP imports and dutiable OAP imports as share of total OAP imports by product over the period 1980-1990. In 1990, the duty-free share of OAP imports -- the share of the value of the final product attributable to U.S. parts and components -- was 50 percent or higher in apparel, semiconductors, circuit breakers, and electrical conductors, but was less than 25 percent in motor vehicles, internal combustion engines, and television receivers.

Mexican trade policy allows domestic and foreign firms to take full advantage of the U.S. OAP. In 1965, Mexico began to permit the creation of export assembly plants under the Border Industrialization Program. ${ }^{8}$ The program exempted the plants, known as maquiladoras, from value-added taxes, import duties on imported inputs, and restrictions on foreign ownership, as long as they exported all of their output (Hansen 1981). The tariff exemption was of particular importance prior to Mexico's liberalization of trade in 1985. The combination of the U.S. OAP and Mexico's maquiladora program implies that a firm that ships U.S.-manufactured components to a plant in Mexico for assembly and then reimports the finished good will, between the two countries, only pay import duties in the United States on the value of Mexican labor and raw materials used in the assembly process. Initially, the maquiladora provisions were limited to a free-trade zone that occupied a twenty-kilometer strip on the Mexican side of the border with the

- One motivation for the Border Industrialization Program was the end of the Bracero Program (1948-1964), which had allowed Mexican nationals to work as agricultural laborers in the United States. The Mexican government was concerned about a sudden influx of returning workers and sought to create employment opportunities for them along the border (Hansen 1981). 
United States. In 1972, the Mexican government began to allow the creation of maquiladoras in most parts of the country and in 1988 the government began to allow the plants to sell up to half of their output on the domestic market (Schoepfle and Perez-Lopez 1990).

Figure 2 shows U.S. OAP imports from Mexico as a share of total U.S. OAP imports for the period 1980-1990. For comparison, Figure 2 also shows the share of total U.S. imports from Mexico. Mexico is the third largest supplier of OAP imports, accounting for $16.99 \%$ of total U.S. OAP imports in 1990..$^{9}$ Table 3 shows Mexico's share of U.S. OAP imports for selected products over the period 1984-1990. Compared to the overall pattern of U.S. OAP imports, OAP imports from Mexico are much less concentrated in motor vehicles: Mexico's share of U.S. OAP imports of motor vehicles did not exceed six percent over the period. Mexico is the major supplier of U.S. OAP imports in a number of electronic and electrical products. In 1990, the country accounted for over 80 percent of U.S. OAP imports of electrical conductors, motors and generators, and television receivers, and over 30 percent of U.S. OAP imports of motor vehicle parts and circuit breakers. During the 1980s, Mexico became a relatively less important source of U.S. OAP apparel imports.

Export assembly plants in Mexico are overwhelmingly concentrated in states on the country's northern border. Table 4 shows employment in maquiladoras for border and non-border states in Mexico over the period 1974-1989. There has been a tremendous expansion in offshore assembly over the last two decades. During the sample period, total export assembly employment (in border and non-border plants combined) in Mexico grew at an average annual rate of $11.3 \%$.

\footnotetext{
The largest suppliers of U.S. OAP imports are Canada and Japan, due mainly to motor vehicle imports from the two countries. In 1987, Canada and Japan accounted for $31.4 \%$ and $21.7 \%$ of total U.S. OAP imports, respectively. Motor vehicles and motor vehicle parts accounted for $77.1 \%$ of OAP imports from Canada and $94.1 \%$ of OAP imports from Japan.
} 
Within border states, maquiladoras are concentrated in a few border cities. In 1989, maquiladora employment in the six largest border cities accounted for $66.7 \%$ of national maquiladora employment. ${ }^{10}$ One factor which may explain the geographic concentration of export assembly plants within the border region is the existence of industrial parks in certain border cities, which provide water and power services and often rent warehouse space and production facilities (Sklair 1989). Such services are scarce or non-existent in other parts of the border region.

In its original conceptualization, U.S. and Mexican supporters of the maquiladora program envisioned a "twin plant" production arrangement, in which a plant located in a U.S. border city would manufacturer components and a plant located in the neighboring Mexican border city would assemble the components into a finished good (Grunwald and Flamm 1985). A common management team located in the United States would run both plants. Under this scheme, the expansion of assembly production in Mexico would lead directly to the expansion of complementary manufacturing activities in the United States. In the large literature on the maquiladora industry, there is near unanimity that the twin-plant system never materialized. It is well-known that maquiladoras have expanded rapidly, but there is a general belief that counterpart development, outside of the growth of transport and related services, has not occurred on the U.S. side of the border. " Curiously, there has been no systematic study of manufacturing activities in U.S. border cities. It is to this issue that I now turn.

10 These cities are Tijuana, Mexicali, Ciudad Juarez, Nuevo Laredo, Reynosa, and Matamoros.

" On the perceived failure of the twin-plant scheme, see Grunwald and Flamm (1985), Sklair (1989), and Wilson (1992). 


\section{The U.S. Border Economy}

While the border region encompasses a vast area, most economic activity, and certainly most manufacturing activity, occurs in a few large cities. For the purposes of this study, I focus on the six largest U.S. border cities and their Mexican counterparts. The U.S.-Mexico border city pairs are the following: San Diego-Tijuana, Imperial County-Mexicali, El Paso-Ciudad Juarez, Laredo-Nuevo Laredo, McAllen-Reynosa, and Brownsville-Matamoros. ${ }^{12}$ The first two U.S. urban areas are in California; the second four are in Texas. Data on one-digit employment and two-digit earnings for U.S. metropolitan statistical areas (MSAs) are available for the period 1970-1990 from the BEA. Data on earnings, employment, value added, and imported inputs in maquiladoras are available for Mexican border cities over the period 1974-1989 from the Mexican National Institute for Statistics, Geography, and Information (INEGI).

U.S. border cities have experienced rapid employment growth over the last two decades. Table 5 shows employment in private non-farm activities and in manufacturing for the U.S. border region over the period 1970-1990. During the 1970s and, to a lesser extent, the 1980s, California and Texas experienced rapid growth in total employment and in manufacturing employment relative to the nation as a whole. With a few exceptions, employment growth has been even more rapid in the border cities. In the 1980s, while California, Texas, and the rest of the nation had near zero employment growth in manufacturing, manufacturing employment grew at an annual average of $3.9 \%$ in McAllen, $2.4 \%$ in San Diego, and $1.5 \%$ in El Paso.

The expansion of manufacturing activities in the border has been concentrated in certain

\footnotetext{
12 The two principal cities opposite Mexicali, Calexico and El Centro, are not large enough to be classified as metropolitan statistical areas (MSAs). I instead measure economic activity in these cities using data on Imperial Country, Califomia, in which both cities are located.
} 
industries. Table 6 shows average annual growth in total earnings, deflated by the U.S. PPI, for selected manufacturing industries in U.S. border cities over the period 1975-1990. Relative to the United States as a whole, average annual earnings growth in durable goods was more rapid in five of the border cities and average annual earnings growth in nondurable goods was more rapid in four of the border cities. The most dramatic differences in earnings growth are for the specific industries that account for most offshore assembly: apparel, electric and electronic equipment, and motor vehicles and motor vehicle parts. While average annual real earnings growth in apparel was nearly flat $(0.3 \%)$ for the nation as a whole, it was $5.2 \%$ in Brownsville, $10.9 \%$ in Laredo, and $8.1 \%$ in McAllen. And while average annual real earnings growth in electric and electronic equipment was $1.8 \%$ for the U.S. as a whole, it was over six percent in each of the border cities and over 15 percent in El Paso, McAllen, and Imperial County. Due to disclosure restrictions, earnings data in motor vehicles are only available for Brownsville, El Paso, and San Diego. In each of these cities, average annual real earnings growth was more than four percent higher than for the nation as a whole.

The industries in which offshore assembly is concentrated now account for the majority of border manufacturing activity. ${ }^{13}$ Table 7 shows the share of two-digit earnings in total manufacturing earnings for border cities and states in 1975 and 1990. In 1990, while apparel accounted for $2.8 \%$ of national manufacturing earnings, it accounted for over 25 percent of manufacturing earnings in Brownsville, El Paso, and McAllen. Similarly, while electrical and electronic equipment accounted for $9.0 \%$ of national manufacturing earnings, the industry

13 Food products has historically been the major manufacturing industry in the U.S. border region. In 1975, it accounted for over 20 percent of manufacturing earnings in Brownsville, Laredo, McAllen, and Imperial County. While the industry is still relatively large in McAllen and Imperial County, over the period 1975-1990 the industry's share of manufacturing earnings fell from $23.8 \%$ to $14.4 \%$ in Brownsville and from $29.3 \%$ to $13.4 \%$ in Laredo. 
accounted for over 14 percent of earnings in El Paso, Laredo, and San Diego.

Some questions remain regarding the nature of the manufacturing activities located in U.S. border cities. While I argue that these activities represent components production and other activities that are complementary to offshore assembly, it is entirely possible that part or all of border manufacturing is unrelated to export manufacturing in Mexico. Unfortunately, the BEA data do not identify whether manufacturing activities take the form of components production, final goods production, or assembly. There is anecdotal evidence, however, which suggests that much U.S. border manufacturing represents components production for Mexican maquiladoras. Reports in the Twin Plant News, a U.S. trade magazine for firms that engage in offshore assembly in Mexico, identify two types of manufacturing activities that predominate in U.S. border cities: plastic injection molding and metal stamping. Both activities are general techniques used to create parts and components for domestic electronic devices and motor vehicles. ${ }^{14}$ Injection molding and metal stamping firms appear to be mostly independent suppliers of major auto companies or name-brand electronics producers. Some of these firm have relocated to the border at the behest of their major buyers.

The data presented in this section are consistent with the hypothesis that the expansion of export assembly activities in Mexican border cities has contributed to an increase in manufacturing activities in U.S. border cities. The expansion of border manufacturing could,

16 Reports in the Twin Plant News state that employment in the El Paso plastic injection molding industry grew by 700 percent between 1981 and 1988 (Mike Roard, "Advanced Technology," Twin Plant News, January 1990, pp. 41-42), and that in 1993 the industry supplied $\$ 200$ million worth of plastic components to Mexico's offshore assembly industry (Clare L. Goldsberry, "An Editorial Perspective," Twin Plant News, March 1993, p. 45). El Paso Community College and the University of Texas at El Paso now offer specialized courses in injection molding techniques (Keith H. Pannell, "Border Education: Responding to the Converging Needs of the Region," Twin Plant News, March 1993, pp. 38-39). 
however, be due to local labor-market conditions, such as low wages arising from an abundant local immigrant labor supply. In the next section, I use more formal techniques to identify the effects of offshore assembly in Mexico on border manufacturing activities in the United States.

\section{Empirical Results}

\section{A. Model Specification}

To study the effects of offshore assembly in Mexico on manufacturing activities in U.S. border cities, I develop a simple model of employment at the city and industry level. As the demand for a city-industry's output expands, the city-industry will increase the amount of labor it employs. Following Hanson (1995), labor demand at the city-industry level can be modelled as a function of sources of demand for city-industry output.

Consider a competitive labor market in which labor demand in city $i$ by industry $j$ at time $t$ is given by the expression,

$$
L^{D_{i j t}}=E\left(X_{i j t}, W_{i j t}\right) e^{e_{i j t}}
$$

where $X_{i j t}$ is a vector of factors that shift labor demand, $W_{i j t}$ is the wage in city-industry $i j$, and $\varepsilon_{y t}$ is an unobserved shock to city-industry labor demand which has mean zero and constant variance $\sigma_{e}$. Let labor supply in the city-industry be given by

$$
L_{i j t}^{S}=g\left(A W G_{i j t}, W_{i j t}\right) \theta^{\mu_{x t t}}
$$

where $A W G_{i j t}$ is the alternative wage for workers in the city industry and $\mu_{i j t}$ represents an unobserved shock to city-industry labor supply that has mean zero and constant variance $\sigma_{\mu}$.

From equations (1) and (2), I derive a reduced-form regression equation for equilibrium 
city-industry employment. I assume that this expression can be written as,

$$
\text { (3) } \quad l n L_{i j t}=\alpha+\gamma \ln A M G_{i j t}+\ln x_{i j t} \beta+v_{i j t}
$$

where $\alpha$ and $\gamma$ are scalars, $\beta$ is a vector of parameters, and the error term $v_{i j t}$ is the weighted sum of the labor demand and labor supply shocks. There is also, of course, an analogous reducedform expression for the equilibrium city-industry wage. Given there are no data on wages at the two-digit industry level, I restrict my attention to employment.

I identify three variables that shift city-industry labor demand: total personal income in the state in which the MSA is located $\left(S I N C_{\ddot{p}}\right)$, total employment in the national industry $\left(U S L_{i j}\right)$, and employment in maquiladoras that are located in the Mexican border city that neighbors the U.S. MSA $\left(M A Q_{i}\right)$. The first two variables capture domestic demand for output by the city industry. The third variable, maquiladora employment, captures foreign demand for city-industry output. To avoid introducing simultaneity bias into the regression, I measure state personal income excluding the MSA on which the observation is taken and measure national industry employment excluding the state in which the MSA is located.

Incorporating the output-demand variables into equation (3), the estimating equation is

$$
\text { (4) } 1 \Omega L_{i j t}=a+\gamma \ln A M G_{i j t}+\beta_{1} \ln S I N C_{i j t}+\beta_{2} \ln U S L_{i j t}+\beta_{3} \ln M A Q_{i t}+v_{i j t}
$$

Two measures of the alternative wage are available: the average state manufacturing wage, which I calculate excluding the MSA on which the observation is taken, and the average wage in private non-farm, non-manufacturing activities in the MSA.

Unobserved factors may cause employment to vary systematically between border cities or over time. A downturn in the Mexican economy may lead to sudden influx of Mexican 
immigrants at all border sites, or the existence of port facilities in one border city may cause it to have higher employment relative to other border cities. To control for idiosyncratic factors that influence city-industry employment, I include dummy variables for the year and city-industry in the regression. Table 8 defines the variables and provides summary statistics.

The variable of interest in equation (4) is $\ln M A Q_{u t}$. If the expansion of offshore assembly in a Mexican border city increases the demand for manufacturing goods produced in the neighboring U.S. border city, the estimated coefficient on $\ln M A Q_{i t}$ will be positive. This would indicate that the increase in offshore assembly increases the demand for local cross-border manufacturing goods, which in turn increases the demand for local cross-border manufacturing labor. Given the concentration of offshore assembly in certain industries, the effect of maquiladora activities may vary across industries. I allow for this possibility in the estimation.

\section{B. Data and Estimation Issues}

One problem for the estimation is that at the two-digit industry level data are available for total earnings but not for total employment. This does not present a issue for estimating reduced-form coefficients on variables that shift labor demand, given that as long as labor supply is not backward bending outward labor-demand shifts increase both earnings and employment. It does, however, present a problem for estimating reduced-form coefficients on variables that shift labor supply. Depending on labor-demand elasticities, shifts in the labor-supply curve may generate earnings and employment changes of opposite sign. To deal with this issue, I adjust earnings by dividing the variable by the average one-digit manufacturing wage in the MSA. ${ }^{15}$

is Estimation results using total earnings deflated by the U.S. PPI as the dependent variable are very similar to results using earnings divided by the average one-digit wage as the dependent variable. 
A second problem is that BEA disclosure restrictions prevent the release of data on industries that contain a single establishment. In the smaller urban areas, such as Laredo and Imperial County, disclosure restrictions apply to over half of the twenty two-digit manufacturing industries. A complete set of observations at the two-digit level is available only for San Diego. My approach is to use data aggregated over durable and nondurable manufacturing industries at the MSA level. The BEA publishes complete earnings data on durable-goods and nondurablegoods industries for all of the MSAs in my sample. The durable-nondurable distinction remains useful for my purposes, given that, from Table 6, the industries that account for most offshore assembly -- electrical and electronic equipment and motor vehicles and motor vehicle parts -- also account for most durable manufacturing activity in U.S. border cities. Hence, I expect that the effects of offshore assembly on employment in U.S. border cities will be stronger for durablegoods industries than for nondurable-goods industries.

A final issue for estimation is that the variable $\ln M A Q_{i t}$ may be correlated with the error term, $\mathrm{U}_{i j \mathrm{r}}$. One source of correlation is measurement error. It may be the case that $\ln M A Q_{i t}$ does not capture all activity in the Mexican border area that creates demand for manufacturing goods produced in the neighboring U.S. border city. Measurement error will tend to bias the coefficient estimate on $\ln M A Q_{i t}$ towards zero (Griliches 1986). A second source of correlation between $\ln M A Q_{i t}$ and $v_{i t}$ is that the allocation of maquiladora activities across Mexican border cities may itself be a function of the characteristics of U.S. border cities. It may be desirable to locate assembly plants opposite a U.S. border city that has a large local consumer market or good highways and warehouse facilities. In such a case the unobserved shocks to U.S. city-industry employment will also affect the level of production in maquiladoras located in the neighboring 
Mexican city. If the level of maquiladora activity in a Mexican border city is correlated with employment shocks in the U.S. border city, the OLS coefficient estimate on maquiladora activities will be biased.

To correct for measurement error and possible endogeneity bias, I use instrumentalvariables (IV) estimators. An ideal instrument is one that is correlated with $\ln M A Q_{i t}$ and uncorrelated with $v_{i g r}$. If there is no serial correlation in the error term, lagged values of the suspect endogenous variable are valid instruments. The instruments I use are current values of the other explanatory variables and lagged values of $\ln M A Q_{i r}$.

\section{Empirical Results}

I report OLS and IV estimation results for equation (4). Observations are pooled across MSAs on durable and nondurable manufacturing industries for the period 1974-1989. I use two measures of the alternative wage, the state manufacturing wage (outside the MSA) and the MSA average wage in non-manufacturing activities.

In Table 9 I report OLS and IV regression results for equation (4), in which I constrain the coefficient on maquiladora employment to be equal for durable and nondurable-goods manufacturing industries. The results are consistent with the hypothesis that growth in offshore assembly in Mexico contributes to the expansion of manufacturing in U.S. border cities. Coefficient estimates on $\ln M A Q$ are positive and statistically significant at the one-percent level in all regressions. The results do not depend on which measure of the alternative wage I use. ${ }^{16}$

The coefficient estimates on $\ln M A Q$ in the IV regressions are approximately one-third

\footnotetext{
16 The very high $R^{2}$ statistics in Tables 9 and 10 are due primarily to the city-industry dummy variables. When the city-industry dummies are excluded from the regression, the adjusted $R^{2}$ falls to approximately 0.42 .
} 
larger than those in the OLS regressions, which is consistent with the presence of measurement error. To determine if there is measurement error/endogeneity bias in the regression, I perform a Hausman (1978) specification test. I reject the null hypothesis that $\ln M A Q$ is uncorrelated with the error term at a one-percent level of significance. The coefficient estimates from the IV regressions should, then, be viewed as the more reliable.

The data presented in section III suggest that the growth of offshore assembly in Mexico has contributed to the expansion of specific manufacturing industries in U.S. border cities. These industries -- electrical and electronic equipment and motor vehicles and motor vehicle parts -produce durable goods. To determine if the expansion of offshore assembly in Mexican border cities has had larger effects for durable-goods manufacturing, I allow the coefficient on $\ln M A Q$ to vary across durable and nondurable-goods industries. Table 10 reports OLS and IV regression results. I again find that the coefficient estimates on $\ln M A Q$ are positive and statistically significant at the one-percent level in all regressions. There is a striking difference between the results in Tables 9 and 10. The coefficient estimates on $\ln M A Q$ for durable-goods industries are nearly twice as large as those for nondurable-goods industries. In the first IV regression (column 2a) the coefficient estimate on maquiladora value added is 0.578 for the durable-goods industry, compared to 0.359 for the nondurable-goods industry. I reject the null hypothesis that the coefficient on $\ln M A Q$ is equal for durable and nondurable-goods industries at a one-percent level of significance in all regressions.

The estimation results are consistent with the hypothesis that the growth of offshore assembly in Mexico has contributed to the growth of complementary manufacturing activities in U.S. border cities. The quantitative effect of maquiladora growth on U.S. border employment 
implied by the coefficient estimates is substantial. IV estimation results (Table 10, column 2a) imply, that a $10 \%$ increase in offshore assembly activities in Mexico lead to a $5.8 \%$ increase in durable-goods manufacturing and a $3.6 \%$ increase in nondurable-goods manufacturing in U.S. border cities. These effects are large, considering that offshore assembly along the Mexican border has been growing at a rate of more than ten percent per year for the last two decades.

\section{Concluding Remarks}

The results of this paper have implications for how the U.S. economy will adjust to NAFTA, conditional on the outcome that NAFTA causes export assembly in Mexico to expand. U.S. border cities are an obvious site in which to locate production of parts and components consumed by Mexican maquiladoras. While manufacturing growth in the U.S. border region bas been largely overlooked in the discussion surrounding North American economic integration, the data tell a very clear story. As maquiladoras in Mexico have expanded over the last two decades, so too have complementary manufacturing activities in U.S. border cities. The estimation results provide strong support for the hypothesis that the growth of maquiladoras in Mexico increases the demand for manufacturing goods produced in U.S. border cities.

A key question is whether the export assembly industry in Mexico will continue to expand with the implementation of NAFTA. In a purely legalistic sense, NAFTA means the end of the maquiladora regime: it eliminates the "in-bond" arrangement, under which Mexican export assembly plants posted a bond for the value of the duties on the inputs they imported from abroad that was later returned to them once the products containing the imported inputs were exported. This does not mean, however, that NAFTA will alter the current pattern of 
specialization in which Mexican plants assemble goods from U.S.-made components and export the goods to the U.S. market. Curiously, none of the computable general equilibrium models developed to study NAFTA address the effects of trade reform on Mexico's export assembly industry. In an appendix I use the partial-equilibrium framework developed by Grossman (1982) to determine what effect NAFTA will have on the offshore-assembly arrangement -- the arrangement in which goods made from U.S. components are assembled in Mexico. While such an approach has obvious limitations, the general thrust of the analysis is sensible.

Given Mexico's low relative wages, it is likely that the country will continue to specialize in the assembly of manufactured goods for the North American market. The more difficult question is which country will produce the components that maquiladoras assemble. The preNAFTA pattern of trade between the United States and Mexico tells us something about each country's comparative advantage. Prior to NAFTA many goods, including television receivers, motor vehicle parts, and apparel, that were produced from U.S. components and assembled in Mexico were consumed in both the United States and Mexico. Even with the pre-NAFTA tariff disadvantage in the Mexican market, U.S.-made components were cheaper than Mexican-made components. The abolition of trade barriers should strengthen the comparative advantage of the United States in components production. Of course, such an argument ignores the possibility that NAFTA will change relative prices enough that the United States no longer has a comparative advantage in components production. This is unlikely, however, given that pre-NAFTA tariffs were low for most products. The most likely scenario is that NAFTA will cause Mexican assembly plants and U.S. components producers to expand, in which case one can expect manufacturing activities in the United States to continue to relocate to the U.S. border region. 


\section{Appendix}

I use the framework in Grossman (1982) to assess the effects of NAFTA on industries that engage in offshore assembly. The analysis considers the pattern of production that would emerge if tariffs were eliminated and pre-NAFTA prices remained constant. Such an exercise ignores the general equilibrium effects of trade reform, but it remains useful as a way to identify who benefits from the lowering of trade barriers, holding constant changes in other industries.

Consider a final good $j$ that is produced in two stages. In stage one, an intermediate good $n$ is produced and in stage two the intermediate good is assembled into a final product. One unit of $n$ is required to produce one unit of $j$. Let $P^{(k,}$, be the price of the final good $j$, where $i$ is the source country for the intermediate good and $k$ is the country in which assembly occurs. Let $P_{n}$ be the price of good $n$ produced in country $i$. There are two countries, the United States, indexed by $U$, and Mexico, indexed by $M$. Both have tariffs on intermediate and final goods, where $t_{h}$ is the tariff on good $h$ in country $i$. There are also costs in shipping goods between countries, where $s_{h}$ is the unit cost of shipping good $h$ from the United States to Mexico, or vice-versa.

I assume that all agents are price takers and that identical goods are consumed in the two countries. In practice, there are three possible structures of production: (1) pure U.S. production, (2) intermediate-good production in the United States and assembly in Mexico, and (3) pure Mexican production. The type 2 structure is the offshore-assembly arrangement. Arbitrage implies that in any given market all types of good $j$ must sell for the same price.

Consider the U.S. market for good $j$. The U.S. price for a type 2 good is

$$
P^{\sigma_{r} \mu_{j}}+t^{\sigma_{j}}\left(P^{\sigma_{r} \mu_{j}}-P^{\sigma_{n}}-\boldsymbol{B}_{z}\right)+\boldsymbol{B}_{j}
$$

The price $P^{U M}{ }_{j}$ is the unit cost of producing the good (which includes the cost $s_{n}$ of transporting the intermediate good from the United States to Mexico for assembly). The final good must be transported from Mexico to the United States, where a tariff is levied on the value added abroad. In the United States, type 2 goods compete with type 1 goods (e.g., television sets, apparel, motor vehicles). While assembly costs are higher for goods wholly produced in the United States, producers of these goods avoid the transport costs and import duties incurred in offshore assembly. Arbitrage requires that the U.S. price for all types of good $j$ be equal:

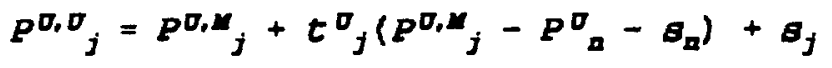

In few, if any, of these markets are goods wholly produced in Mexico consumed in the United States. It must then be true that

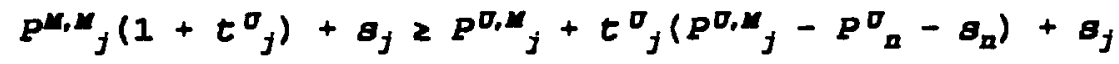

The price of goods wholly produced in Mexico, inclusive of tariffs and transport costs, exceeds the price of offshore-assembly goods and goods wholly produced in the United States. 
Given (A2) and (A3), the effects of eliminating tariffs are ambiguous. Depending of the sign of $P^{N . M}{ }_{j}-P^{U N . M}$, NAFTA may or may not cause goods wholly produced in Mexico to be sold in the U.S. market. Pre-NAFTA competition in the Mexican market implies price relationships that help resolve this ambiguity. Suppose that Mexico consumes quantities of good $j$ that are wholly produced domestically (e.g., apparel, some motor vehicles). If Mexico also consumes goods wholly produced in the United States, it must be true that

(A4)

$$
P^{N_{1} x_{j}}=P^{\sigma_{0} \sigma_{j}}\left(1+t^{N_{j}}\right)+s_{j}
$$

If, instead or in addition, Mexico consumes offshore-assembly goods, it must be true that

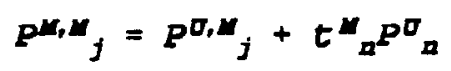

Equation (A5) shows that offshore-assembly goods sold in Mexico are required to pay duties on the imported inputs used in production. (A4) and (A5) may hold simultaneously.

Consider the effects of eliminating tariffs in both countries. Take first the case in which prior to NAFTA Mexico consumes quantities of good $j$ produced under offshore assembly. At pre-NAFTA prices, equations (A2) and (A5) imply that

$$
\begin{array}{ll}
\left(A 2^{\prime}\right) & P^{\sigma_{0} \sigma_{j}}>P^{\sigma_{0} \alpha_{j}}+\theta_{j} \\
\left(A 5^{\prime}\right) & P^{\|, \alpha_{j}}>P^{\sigma_{0} \|_{j}}
\end{array}
$$

Offshore assembly becomes the least-cost strategy of producing good $j$ for both markets. This would cause U.S. components producers and Mexican assembly plants to expand and Mexican components producers and U.S. assembly plants to contract. Now consider the case where prior to NAFTA goods wholly produced in the United States are consumed in Mexico. At pre-NAFTA prices it is again true that equation (A2') holds and from equation (A4) it is now true that

$$
\left(A d^{\prime}\right) \quad P^{\mu, x_{j}}>P^{\sigma_{0} \sigma_{j}}+\boldsymbol{s}_{j}
$$

Combining equations (A2') and (A4'), it is clear that in this case also offshore assembly is the least-cost production strategy for both markets. Holding constant changes in other industries, NAFTA causes offshore assembly to expand.

In addition to ignoring general-equilibrium effects, the analysis ignores the existence of countries outside NAFTA and the effects of scale economies. The second omission is likely to be the more serious. If production in manufacturing is subject to increasing return to scale, NAFTA may lead to greater specialization in components production in all three countries. In this event NAFTA would cause components production to expand in both the United States and Mexico. Even in this case, however, there is still no reason to believe that product assembly in Mexico would contract. As long as Mexico specializes in assembly, U.S. components producers would have an incentive to locate a portion of their activities in the U.S. border region. 


\section{References}

Brown, D.K., A.V. Deardorff, and R.M. Stern. 1992. "North American Integration." Economic Journal 102: 1507-1519.

Finger, J.M. 1976. "Trade and Domestic Effects of the Offshore Assembly Provision of the U.S. Tariff." American Economic Review 66: 598-611.

Griliches, Z. 1986. "Economic Data Issues." In Z. Griliches and M.D. Intriligator, eds., Handbook of Econometrics, Volume III, Amsterdam: North-Holland.

Griliches, Z. and J.A. Hausman. 1986. "Errors in Variables in Panel Data." Joumal of Econometrics 31: 93-118.

Grossman, G. 1982. "Offshore Assembly Provisions and the Structure of Protection." Journal of Intemational Economics 12: 301-312.

Grunwald, J. and K. Flamm. 1985. The Global Factory: Foreign Assembly and International Trade. Washington: The Brookings Institution.

Hansen, N. 1981. The Border Economy: Regional Development in the Southwest. Austin: University of Texas Press.

Hanson, G. 1995. "U.S.-Mexico Integration and Regional Economies: Evidence from BorderCity Pairs," University of Texas.

Henderson, J.V. 1993. "Some Favorable Impacts of a U.S.-Mexico Free Trade Agreement on U.S. Urban Employment." In P. Garber, ed., The Mexico-U.S. Free Trade Agreement, Cambridge: MIT Press.

Mendez, J.A, T. Murray, and D.J. Rousslang. 1991. "US-Mexico Employment Effects of Repealing the US Offshore Assembly Provision." Applied Economics 23: 553-566.

Mendez, J.A. 1993. "The Welfare Effects of Repealing the U.S. Offshore Assembly Provision." Joumal of International Economics. 34: 1-22.

Schoepfle, G. and J. Perez-Lopez. 1988. "U.S. Employment Impact of TSUS 806.30 and 807.00 Provisions and Mexican Maquiladoras: A Survey of Issues and Estimates." Economic Discussion Paper 29, U.S. Department of Labor, Washington, DC.

Schoepfle, G. and J. Perez-Lopez. 1990. "Employment Implications of Export Assembly Operations in Mexico and the Caribbean Basin." Commission for the Study of International Migration and Cooperative Economic Development, Working Paper No. 16. 
Sklair, L. 1989. A ssembling for Development: The Maquila Industry in Mexico and the United States. New York: Unwin Hyman.

U.S. International Trade Commission. 1988a. The Use and Economic Impact of TSUS Items 806.30 and 807.00. Publication 2053 (Washington, DC).

U.S. International Trade Commission. 1988b. Imports under Items 806.30 and 807.00 of the Tariff Schedules of the United States, 1984-87. Publication 2144 (Washington, DC).

Wilson, P.A. 1992. Exports and Local Development: Mexico's New Maquiladoras. Austin, TX: University of Texas Press. 
Table 1: U.S. OAP Imports of Selected Products, 1980-1990

OAP Imports of Product as Share of

\begin{tabular}{|c|c|c|c|c|}
\hline Year & Product & All OAP Imports & Dutiable Imports & Duty-Free Imports \\
\hline 80 & Apparel, Textiles & 0.043 & 0.022 & 0.010 \\
\hline 82 & Apparel, Textiles & 0.036 & 0.019 & 0.085 \\
\hline 84 & Apparel, Textiles & 0.032 & 0.016 & 0.082 \\
\hline 86 & Apparel, Textiles & 0.039 & 0.018 & 0.144 \\
\hline 88 & Apparel, Textiles & 0.032 & 0.019 & 0.078 \\
\hline 90 & Apparel, Textiles & 0.046 & 0.032 & 0.081 \\
\hline 80 & Machinery, Equipment & 0.886 & 0.927 & 0.776 \\
\hline 82 & Machinery, Equipment & 0.890 & 0.926 & 0.792 \\
\hline 84 & Machinery, Equipment & 0.919 & 0.954 & 0.817 \\
\hline 86 & Machinery, Equipment & 0.910 & 0.953 & 0.702 \\
\hline 88 & Machinery, Equipment & 0.923 & 0.950 & 0.832 \\
\hline 90 & Machinery, Equipment & 0.902 & 0.930 & 0.830 \\
\hline 80 & Motor Vehicle Parts & 0.048 & 0.061 & 0.012 \\
\hline 82 & Motor Vehicle Parts & 0.017 & 0.018 & 0.014 \\
\hline 84 & Motor Vehicle Parts & 0.024 & 0.023 & 0.026 \\
\hline 86 & Motor Vehicle Parts & 0.025 & 0.022 & 0.035 \\
\hline 88 & Motor Vehicle Parts & 0.053 & 0.053 & 0.055 \\
\hline 90 & Motor Vehicle Parts & 0.038 & 0.034 & 0.048 \\
\hline 80 & Motor Vehicles & 0.375 & 0.507 & 0.016 \\
\hline 82 & Motor Vehicles & 0.439 & 0.584 & 0.022 \\
\hline 84 & Motor Vehicles & 0.447 & 0.589 & 0.028 \\
\hline 86 & Motor Vehicles & 0.641 & 0.744 & 0.148 \\
\hline 88 & Motor Vehicles & 0.598 & 0.672 & 0.347 \\
\hline 90 & Motor Vehicles & 0.591 & 0.672 & 0.385 \\
\hline 80 & Circuit Breakers & 0.012 & 0.007 & 0.027 \\
\hline 82 & Circuit Breakers & 0.014 & 0.009 & 0.031 \\
\hline 84 & Circuit Breakers & 0.013 & 0.007 & 0.033 \\
\hline 86 & Circuit Breakers & 0.013 & 0.005 & 0.046 \\
\hline 88 & Circuit Breakers & 0.010 & 0.005 & 0.027 \\
\hline 90 & Circuit Breakers & 0.023 & 0.007 & 0.063 \\
\hline 80 & Electrical Conductors & 0.011 & 0.006 & 0.023 \\
\hline 82 & Electrical Conductors & 0.013 & 0.007 & 0.031 \\
\hline 84 & Electrical Conductors & 0.018 & 0.009 & 0.045 \\
\hline 86 & Electrical Conductors & 0.023 & 0.011 & 0.080 \\
\hline 88 & Electrical Conductors & 0.016 & 0.008 & 0.045 \\
\hline 90 & Electrical Conductors & 0.018 & 0.010 & 0.038 \\
\hline
\end{tabular}


Table 1: continued

\begin{tabular}{|c|c|c|c|c|}
\hline \multirow[b]{2}{*}{ Year } & \multirow[b]{2}{*}{ Product } & \multicolumn{3}{|c|}{ OAP Imports of Product as Share of } \\
\hline & & All OAP Imports & Dutiable Imports & Duty-Free Imports \\
\hline 80 & Combustion Engines & 0.004 & 0.004 & 0.005 \\
\hline 82 & Combustion Engines & 0.012 & 0.010 & 0.017 \\
\hline 84 & Combustion Engines & 0.028 & 0.027 & 0.029 \\
\hline 86 & Combustion Engines & 0.029 & 0.027 & 0.037 \\
\hline 88 & Combustion Engines & 0.035 & 0.039 & 0.022 \\
\hline 90 & Combustion Engines & 0.027 & 0.033 & 0.011 \\
\hline 80 & Office Machines & 0.044 & 0.044 & 0.045 \\
\hline 82 & Office Machines & 0.042 & 0.041 & 0.044 \\
\hline 84 & Office Machines & 0.064 & 0.069 & 0.052 \\
\hline 86 & Office Machines & 0.017 & 0.016 & 0.024 \\
\hline 88 & Office Machines & 0.035 & 0.036 & 0.033 \\
\hline 90 & Office Machines & 0.028 & 0.028 & 0.025 \\
\hline 80 & Semiconductors & 0.176 & 0.089 & 0.413 \\
\hline 82 & Semiconductors & 0.170 & 0.084 & 0.417 \\
\hline 84 & Semiconductors & 0.161 & 0.084 & 0.388 \\
\hline 86 & Semiconductors & 0.015 & 0.008 & 0.047 \\
\hline 88 & Semiconductors & 0.059 & 0.035 & 0.142 \\
\hline 90 & Semiconductors & 0.065 & 0.040 & 0.127 \\
\hline 80 & Television Receivers & 0.009 & 0.011 & 0.003 \\
\hline 82 & Television Receivers & 0.007 & 0.008 & 0.003 \\
\hline 84 & Television Receivers & 0.005 & 0.007 & 0.002 \\
\hline 86 & Television Receivers & 0.012 & 0.012 & 0.012 \\
\hline 88 & Television Receivers & 0.012 & 0.012 & 0.011 \\
\hline 90 & Television Receivers & 0.019 & 0.021 & 0.015 \\
\hline
\end{tabular}

\section{Notes}

The following note applies to Tables 1-3. For the time period 1980-1990, OAP imports are those entered under items 806.30 and 807.00 of TSUSA. The dutiable portion of OAP imports is that equal to the value added by foreign sources; the duty-free portion is that equal to the value of U.S.-made parts and components. All products that follow Machinery and Equipment in the table belong to that product category.

Source: Imports under Items 806.30 and 807.00 of the Tariff Schedule of the United States, U.S. International Trade Commission, various editions. 
Table 2: Dutiable and Duty-Free Content of OAP Imports, 1980-1990

\begin{tabular}{|c|c|c|c|}
\hline \multirow{2}{*}{ Year } & \multirow[b]{2}{*}{ Product } & \multicolumn{2}{|c|}{ Share of OAP Imports of Product that are } \\
\hline & & Dutiable & Duty-Free \\
\hline 80 & All Products & 0.740 & 0.260 \\
\hline 90 & All Products & 0.723 & 0.277 \\
\hline 80 & Apparel, Textiles & 0.375 & 0.625 \\
\hline 90 & Apparel, Textiles & 0.501 & 0.499 \\
\hline 80 & Machinery, Equipment & 0.766 & 0.235 \\
\hline 90 & Machinery, Equipment & 0.740 & 0.260 \\
\hline 80 & Motor Vehicle Parts & 0.932 & 0.068 \\
\hline 90 & Motor Vehicle Parts & 0.642 & 0.358 \\
\hline 80 & Motor Vehicles & 0.989 & 0.011 \\
\hline 90 & Motor Vehicles & 0.816 & 0.184 \\
\hline 80 & Circuit Breakers & 0.417 & 0.583 \\
\hline 90 & Circuit Breakers & 0.227 & 0.773 \\
\hline 80 & Electrical Conductors & 0.433 & 0.567 \\
\hline 90 & Electrical Conductors & 0.408 & 0.592 \\
\hline 80 & Combustion Engines & 0.664 & 0.336 \\
\hline 90 & Combustion Engines & 0.879 & 0.121 \\
\hline 80 & Office Machines & 0.726 & 0.274 \\
\hline 90 & Office Machines & 0.742 & 0.258 \\
\hline 80 & Semiconductors & 0.370 & 0.630 \\
\hline 90 & Semiconductors & 0.447 & 0.553 \\
\hline 80 & Television Receivers & 0.905 & 0.095 \\
\hline 90 & Television Receivers & 0.782 & 0.218 \\
\hline
\end{tabular}

See notes to Table 1 . 
Table 3: OAP Imports from Mexico as Share of Total U.S. OAP Imports, 1984-1990

Share of U.S. OAP Imports from Mexico

\begin{tabular}{|c|c|c|c|c|}
\hline Year & Product & All OAP & Dutiable & Duty-Free \\
\hline 84 & Apparel, Textiles & 0.319 & 0.198 & 0.388 \\
\hline 86 & Apparel, Textiles & 0.326 & 0.198 & 0.401 \\
\hline 88 & Apparel, Textiles & 0.238 & 0.151 & 0.310 \\
\hline 90 & Apparel, Textiles & 0.236 & 0.134 & 0.337 \\
\hline 84 & Machinery, Equipment & 0.154 & 0.099 & 0.343 \\
\hline 86 & Machinery, Equipment & 0.157 & 0.092 & 0.578 \\
\hline 88 & Machinery, Equipment & 0.130 & 0.085 & 0.300 \\
\hline 90 & Machinery, Equipment & 0.153 & 0.108 & 0.282 \\
\hline 84 & Motor Vehicle Parts & 0.407 & 0.292 & 0.701 \\
\hline 86 & Motor Vehicle Parts & 0.219 & 0.089 & 0.618 \\
\hline 88 & Motor Vehicle Parts & 0.159 & 0.071 & 0.447 \\
\hline 90 & Motor Vehicle Parts & 0.359 & 0.198 & 0.647 \\
\hline 84 & Motor Vehicles & 0.008 & 0.003 & 0.286 \\
\hline 86 & Motor Vehicles & 0.036 & 0.021 & 0.398 \\
\hline 88 & Motor Vehicles & 0.039 & 0.029 & 0.105 \\
\hline 90 & Motor Vehicles & 0.058 & 0.042 & 0.128 \\
\hline 84 & Circuit Breakers & 0.725 & 0.623 & 0.786 \\
\hline 86 & Circuit Breakers & 0.778 & 0.711 & 0.816 \\
\hline 88 & Circuit Breakers & 0.797 & 0.725 & 0.847 \\
\hline 90 & Circuit Breakers & 0.429 & 0.633 & 0.369 \\
\hline 84 & Electrical Conductors & 0.855 & 0.741 & 0.920 \\
\hline 86 & Electrical Conductors & 0.832 & 0.715 & 0.907 \\
\hline 88 & Electrical Conductors & 0.902 & 0.822 & 0.948 \\
\hline 90 & Electrical Conductors & 0.952 & 0.935 & 0.964 \\
\hline 84 & Combustion Engines & 0.661 & 0.605 & 0.817 \\
\hline 86 & Combustion Engines & 0.590 & 0.536 & 0.776 \\
\hline 88 & Combustion Engines & 0.218 & 0.164 & 0.531 \\
\hline 90 & Combustion Engines & 0.136 & 0.101 & 0.393 \\
\hline 84 & Motors \& Generators & 0.681 & 0.547 & 0.847 \\
\hline 86 & Motors \& Generators & 0.793 & 0.682 & 0.908 \\
\hline 88 & Motors \& Generators & 0.815 & 0.692 & 0.943 \\
\hline 90 & Motors \& Generators & 0.889 & 0.809 & 0.963 \\
\hline
\end{tabular}


Table 3: continued

\begin{tabular}{|c|c|c|c|c|}
\hline \multirow[b]{2}{*}{ Year } & \multirow[b]{2}{*}{ Product } & \multicolumn{3}{|c|}{ Share of U.S. OAP Imports from Mexico } \\
\hline & & All OAP & Dutiable & Duty-Free \\
\hline 84 & Office Machines & 0.131 & 0.078 & 0.343 \\
\hline 86 & Office Machines & 0.057 & 0.045 & 0.096 \\
\hline 88 & Office Machines & 0.141 & 0.112 & 0.246 \\
\hline 90 & Office Machines & 0.161 & 0.115 & 0.290 \\
\hline 84 & Semiconductors & 0.047 & 0.038 & 0.053 \\
\hline 86 & Semiconductors & 0.109 & 0.083 & 0.132 \\
\hline 88 & Semiconductors & 0.054 & 0.041 & 0.065 \\
\hline 90 & Semiconductors & 0.060 & 0.052 & 0.066 \\
\hline 84 & Television Receivers & 0.386 & 0.410 & 0.114 \\
\hline 86 & Television Receivers & 0.779 & 0.752 & 0.894 \\
\hline 88 & Television Receivers & 0.902 & 0.883 & 0.971 \\
\hline 90 & Television Receivers & 0.924 & 0.912 & 0.966 \\
\hline
\end{tabular}

See notes to Table 1 . 
Table 4: Maquiladora Employment in Mexico, 1974-1989

\begin{tabular}{|c|c|c|c|c|}
\hline \multirow[b]{2}{*}{ Year } & \multicolumn{2}{|c|}{ Mexico Border States } & \multicolumn{2}{|c|}{ Mexico Non-Border States } \\
\hline & Employment & Share of Total & Employment & Share of Total \\
\hline 1974 & 70,929 & 0.934 & 5,045 & 0.066 \\
\hline 1975 & 61,912 & 0.921 & 5,302 & 0.079 \\
\hline 1976 & 67,258 & 0.903 & 7,238 & 0.097 \\
\hline 1977 & 70,494 & 0.899 & 7,939 & 0.101 \\
\hline 1978 & 82,130 & 0.906 & 8,574 & 0.095 \\
\hline 1979 & 100,138 & 0.899 & 11,227 & 0.101 \\
\hline 1980 & 106,208 & 0.888 & 13,338 & 0.112 \\
\hline 1981 & 116,142 & 0.887 & 14,831 & 0.113 \\
\hline 1982 & 112,875 & 0.888 & 14,173 & 0.112 \\
\hline 1983 & 134,086 & 0.889 & 16,781 & 0.111 \\
\hline 1984 & 175,778 & 0.880 & 23,906 & 0.120 \\
\hline 1985 & 184,664 & 0.871 & 27,304 & 0.129 \\
\hline 1986 & 210,635 & 0.843 & 39,198 & 0.157 \\
\hline 1987 & 249,595 & 0.818 & 55,658 & 0.182 \\
\hline 1988 & 297,127 & 0.804 & 72,362 & 0.196 \\
\hline 1989 & 338,516 & 0.788 & 91,209 & 0.212 \\
\hline
\end{tabular}

Average Annual

Growth Rate

0.104

$--$

0.193

\section{Notes}

Border states refer to states in Mexico that border the United States. The employment share is the share of national maquiladora employment. The average annual growth rate is the average annual log change over the period.

Source: Mexico National Institute of Statistics, Geography, and Information (INEGI). 
Table 5: Employment in U.S. Border Cities and Border States, 1970-1990

\begin{tabular}{|c|c|c|c|c|c|}
\hline \multirow[b]{2}{*}{ Year } & \multirow[b]{2}{*}{ Region } & \multicolumn{2}{|c|}{$\begin{array}{l}\text { Private, Non-Farm Employment } \\
\text { ('000s of workers) }\end{array}$} & \multicolumn{2}{|c|}{$\begin{array}{l}\text { Manufacturing Employment } \\
\text { ('000s of workers) }\end{array}$} \\
\hline & & Employment & Annual Growth & Employment & Annual Growth \\
\hline 70 & U.S. & $70,868.2$ & -- & $19,684.4$ & -- \\
\hline 80 & U.S. & $91,121.8$ & 0.025 & $20,776.6$ & 0.005 \\
\hline 90 & U.S. & $114,610.3$ & 0.023 & $19,755.6$ & -0.005 \\
\hline 70 & Texas & $3,825.2$ & - & 755.8 & -- \\
\hline 80 & Texas & $6,039.1$ & 0.046 & $1,067.8$ & 0.035 \\
\hline 90 & Texas & $7,649.8$ & 0.024 & $1,033.7$ & -0.003 \\
\hline 70 & Brownsville & 36.1 & -- & 5.0 & -- \\
\hline 80 & Brownsville & 63.4 & 0.056 & 11.8 & 0.086 \\
\hline 90 & Brownsville & 79.1 & 0.022 & 12.1 & 0.003 \\
\hline 70 & El Paso & 101.9 & -- & 23.9 & -- \\
\hline 80 & El Paso & 156.0 & 0.043 & 36.4 & 0.042 \\
\hline 90 & El Paso & 208.4 & 0.029 & 42.4 & 0.015 \\
\hline 70 & Laredo & 18.6 & -- & 1.1 & -- \\
\hline 80 & Laredo & 30.3 & 0.049 & 2.1 & 0.064 \\
\hline 90 & Laredo & 44.3 & 0.038 & 1.9 & -0.013 \\
\hline 70 & McAllen & 36.3 & -- & 3.5 & -- \\
\hline 80 & McAllen & 70.5 & 0.067 & 9.5 & 0.099 \\
\hline 90 & McAllen & 103.9 & 0.037 & 14.0 & 0.039 \\
\hline 70 & California & $6,917.9$ & -- & $1,594.5$ & -- \\
\hline 80 & California & $10,315.8$ & 0.040 & $2,074.1$ & 0.026 \\
\hline 90 & California & $14,330.9$ & 0.033 & $2,229.4$ & 0.007 \\
\hline 70 & Imperial & 18.1 & -- & 1.6 & -- \\
\hline 80 & Imperial & 27.7 & 0.043 & 2.0 & 0.025 \\
\hline 90 & Imperial & 37.8 & 0.031 & 1.6 & -0.023 \\
\hline 70 & San Diego & 376.6 & -- & 67.8 & - \\
\hline 80 & San Diego & 680.0 & 0.059 & 112.2 & 0.050 \\
\hline 90 & San Diego & $1,106.3$ & 0.049 & 142.3 & 0.024 \\
\hline
\end{tabular}

\section{Notes}

The following note applies to Tables 5-7. The cities listed are Metropolitan Statistical Areas, as defined by the BEA (except for Imperial, which is Imperial County, California). MSAs typically encompass groups of cities that form a contiguous urban area. Annual growth refers to the annual average log change in employment over the previous decade.

Source: BEA, Regional Economic Information System. 
Table 6: Average Annual Growth in Total Earnings by Manufacturing Industry, 1975-1990

Average Annual Growth in Total Earnings

\begin{tabular}{|c|c|c|c|c|}
\hline \multirow[b]{2}{*}{ Border City } & \multirow[b]{2}{*}{ Industry } & \multicolumn{3}{|c|}{ (log change in total earnings/U.S. PPI) } \\
\hline & & City & State & Nation \\
\hline Brownsville & Manufacturing & 0.020 & 0.034 & 0.021 \\
\hline El Paso & Manufacturing & 0.034 & 0.034 & \\
\hline Laredo & Manufacturing & 0.027 & 0.034 & \\
\hline McAllen & Manufacturing & 0.069 & 0.034 & \\
\hline Imperial & Manufacturing & -0.014 & 0.038 & \\
\hline San Diego & Manufacturing & 0.060 & 0.038 & \\
\hline Brownsville & Nondurable Goods & 0.017 & 0.031 & 0.023 \\
\hline El Paso & Nondurable Goods & 0.023 & 0.031 & \\
\hline Laredo & Nondurable Goods & 0.024 & 0.031 & \\
\hline McAllen & Nondurable Goods & 0.066 & 0.031 & \\
\hline Imperial & Nondurable Goods & -0.029 & 0.035 & \\
\hline San Diego & Nondurable Goods & 0.066 & 0.035 & \\
\hline Brownsville & Apparel & 0.052 & -0.001 & 0.003 \\
\hline El Paso & Apparel & 0.002 & -0.001 & \\
\hline Laredo & Apparel & 0.109 & -0.001 & \\
\hline McAllen & Apparel & 0.081 & -0.001 & \\
\hline Imperial & Apparel & -0.044 & 0.046 & \\
\hline San Diego & Apparel & 0.012 & 0.046 & \\
\hline Brownsville & Durable Goods & 0.024 & 0.036 & 0.019 \\
\hline El Paso & Durable Goods & 0.058 & 0.036 & \\
\hline Laredo & Durable Goods & 0.031 & 0.036 & \\
\hline McAllen & Durable Goods & 0.079 & 0.036 & \\
\hline Imperial & Durable Goods & 0.013 & 0.040 & \\
\hline San Diego & Durable Goods & 0.059 & 0.040 & \\
\hline Brownsville & Elec. \& Electronic Equip. & 0.068 & 0.071 & 0.018 \\
\hline El Paso & Elec. \& Electronic Equip. & 0.198 & 0.071 & \\
\hline Laredo & Elec. \& Electronic Equip. & 0.094 & 0.071 & \\
\hline McAllen & Elec. \& Electronic Equip. & 0.162 & 0.071 & \\
\hline Imperial & Elec. \& Electronic Equip. & 0.158 & 0.028 & \\
\hline San Diego & Elec. \& Electronic Equip. & 0.075 & 0.028 & \\
\hline Brownsville & Motor Vehicles & 0.182 & 0.030 & 0.018 \\
\hline El Paso & Motor Vehicles & 0.060 & 0.030 & \\
\hline San Diego & Motor Vehicles & 0.068 & 0.003 & \\
\hline
\end{tabular}


Table 7: Regional Industry Shares of Regional Manufacturing Earnings, 1975 and 1990

\begin{tabular}{|c|c|c|c|}
\hline Region & Industry & 1975 & 1990 \\
\hline U.S. & Nondurable Goods & 0.371 & 0.382 \\
\hline Texas & Nondurable Goods & 0.439 & 0.422 \\
\hline Brownsville & Nondurable Goods & 0.532 & 0.506 \\
\hline El Paso & Nondurable Goods & 0.692 & 0.570 \\
\hline Laredo & Nondurable Goods & 0.576 & 0.552 \\
\hline McAllen & Nondurable Goods & 0.796 & 0.762 \\
\hline California & Nondurable Goods & 0.304 & 0.290 \\
\hline Imperial & Nondurable Goods & 0.715 & 0.574 \\
\hline San Diego & Nondurable Goods & 0.162 & 0.178 \\
\hline U.S. & Apparel & 0.037 & 0.028 \\
\hline Texas & Apparel & 0.044 & 0.026 \\
\hline Brownsville & Apparel & 0.155 & 0.251 \\
\hline El Paso & Apparel & 0.443 & 0.268 \\
\hline McAllen & Apparel & 0.250 & 0.302 \\
\hline California & Apparel & 0.031 & 0.034 \\
\hline San Diego & Apparel & 0.024 & 0.012 \\
\hline U.S. & Durable Goods & 0.630 & 0.618 \\
\hline Texas & Durable Goods & 0.561 & 0.578 \\
\hline Brownsville & Durable Goods & 0.468 & 0.494 \\
\hline El Paso & Durable Goods & 0.308 & 0.430 \\
\hline Laredo & Durable Goods & 0.424 & 0.448 \\
\hline McAllen & Durable Goods & 0.204 & 0.238 \\
\hline California & Durable Goods & 0.696 & 0.710 \\
\hline Imperial & Durable Goods & 0.285 & 0.427 \\
\hline San Diego & Durable Goods & 0.838 & 0.822 \\
\hline U.S. & Elec. \& Electronic Equip. & 0.093 & 0.090 \\
\hline Texas & Elec. \& Electronic Equip. & 0.069 & 0.120 \\
\hline Brownsville & Elec. \& Electronic Equip. & 0.056 & 0.115 \\
\hline El Paso & Elec. \& Electronic Equip. & 0.016 & 0.176 \\
\hline Laredo & Elec. \& Electronic Equip. & 0.052 & 0.142 \\
\hline McAllen & Elec. \& Electronic Equip. & 0.013 & 0.051 \\
\hline California & Elec. \& Electronic Equip. & 0.155 & 0.132 \\
\hline San Diego & Elec. \& Electronic Equip. & 0.127 & 0.160 \\
\hline U.S. & Motor Vehicles & 0.059 & 0.057 \\
\hline Texas & Motor Vehicles & 0.015 & 0.014 \\
\hline Brownsville & Motor Vehicles & 0.039 & 0.104 \\
\hline El Paso & Motor Vehicles & 0.006 & 0.036 \\
\hline California & Motor Vehicles & 0.021 & 0.012 \\
\hline San Diego & Motor Vehicles & 0.004 & 0.004 \\
\hline
\end{tabular}


Table 8: Summary Statistics for Regression Variables

\begin{tabular}{||l|l|l|l|l|}
\hline Variable & Definition & Mean & St. Dev. & Obs. No. \\
\hline $\ln L$ & $\begin{array}{l}\text { Log MSA industry earnings/ average } \\
\text { MSA manufacturing wage } \\
\text { (dependent variable) }\end{array}$ & 8.467 & 1.490 & 180 \\
\hline InAWG1 & $\begin{array}{l}\text { Log average state manufacturing wage } \\
\text { outside of MSA (deflated by US CPI) }\end{array}$ & -1.345 & 0.036 & 180 \\
\hline $\operatorname{lnAWG2}$ & $\begin{array}{l}\text { Log average MSA wage in private non- } \\
\text { farm, non-manufacturing activities } \\
\text { (deflated by US CPI) }\end{array}$ & -1.970 & 0.111 & 180 \\
\hline $\operatorname{lnSINC}$ & $\begin{array}{l}\text { Log state personal income outside of } \\
\text { MSA (deflated by US PPI) }\end{array}$ & 14.732 & 0.358 & 180 \\
\hline $\operatorname{lnUSL}$ & $\begin{array}{l}\text { Log national-industry earnings/ national- } \\
\text { industry manufacturing wage, outside of } \\
\text { state in which MSA is located }\end{array}$ & 16.007 & 0.275 & 180 \\
\hline InMAQ & $\begin{array}{l}\text { Log maquiladora value added (converted } \\
\text { into dollars and deflated by the U.S. PPI } \\
\text { in the Mexican border city that neighbors } \\
\text { the U.S. MSA }\end{array}$ & -0.755 & 0.115 & 90 \\
\hline
\end{tabular}

Observations for all variables are for the period 1975-1989. 
Table 9: U.S. Border-City Manufacturing Employment Estimation Results (standard errors in parentheses)

\begin{tabular}{|c|c|c|c|c|}
\hline Estimation Method & OLS & OLS & IV & IV \\
\hline Variable & (1a) & (1b) & (2a) & (2b) \\
\hline $\ln A W G 1$ & $\begin{array}{c}-1.9878 \\
(1.9955)\end{array}$ & & $\begin{array}{l}-2.4398 \\
(2.0390)\end{array}$ & \\
\hline $\ln A W G 2$ & & $\begin{array}{c}0.3966 \\
(0.5391)\end{array}$ & & $\begin{array}{c}0.6251 \\
(0.5555)\end{array}$ \\
\hline $\ln S I N C$ & $\begin{array}{c}0.9544 \\
(0.8121)\end{array}$ & $\begin{array}{c}0.1402 \\
(0.7019)\end{array}$ & $\begin{array}{c}0.8929 \\
(0.8279)\end{array}$ & $\begin{array}{l}-0.2141 \\
(0.7256)\end{array}$ \\
\hline $\operatorname{lnUSL}$ & $\begin{array}{l}-1.1096 \\
(0.9034)\end{array}$ & $\begin{array}{l}-1.0212 \\
(0.9103)\end{array}$ & $\begin{array}{l}-1.2230 \\
(0.9213)\end{array}$ & $\begin{array}{l}-1.0971 \\
(0.9312)\end{array}$ \\
\hline $\ln M A Q$ & $\begin{array}{l}0.3329^{* *} \\
(0.0629)\end{array}$ & $\begin{array}{l}0.3347^{* *} \\
(0.0636)\end{array}$ & $\begin{array}{l}0.4794^{* *} \\
(0.0792)\end{array}$ & $\begin{array}{l}0.4952^{* *} \\
(0.0809)\end{array}$ \\
\hline $\begin{array}{l}\text { Hausman Specification } \\
\text { Test statistic }\end{array}$ & & & $-3.324^{* *}$ & $-3.546^{* *}$ \\
\hline Adjusted $\mathrm{R}^{2}$ & 0.984 & 0.984 & 0.983 & 0.985 \\
\hline Number of Observations & 168 & 168 & 168 & 168 \\
\hline
\end{tabular}

* (**) Indicates statistical significance at the five-percent (one-percent) level. Observations are pooled across durable and nondurable manufacturing industries in six U.S, border urban areas (San Diego, Imperial County, El Paso, Laredo, McAllen, and Brownsville) over the period 19741989. All regressions include dummy variables for the city-industry and the year, which are not shown. Instruments include the (presumed) exogenous independent variables and the first lag of InMAQ. 
Table 10: Estimation Results with Industry-Varying Coefficients (standard errors in parentheses)

\begin{tabular}{|c|c|c|c|c|}
\hline Estimation Method & OLS & OLS & IV & IV \\
\hline Variable & (1a) & (lb) & (2a) & (2b) \\
\hline $\ln A W G 1$ & $\begin{array}{c}-1.9282 \\
(1.8930)\end{array}$ & & $\begin{array}{c}-2.3644 \\
(1.9438)\end{array}$ & \\
\hline $\ln A W G 2$ & & $\begin{array}{c}0.5138 \\
(0.5114)\end{array}$ & & $\begin{array}{r}0.7432 \\
(0.5282)\end{array}$ \\
\hline $\operatorname{lnSINC}$ & $\begin{array}{c}1.0406 \\
(0.7706)\end{array}$ & $\begin{array}{c}0.1652 \\
(0.6648)\end{array}$ & $\begin{array}{c}0.9825 \\
(0.7896)\end{array}$ & $\begin{array}{l}-0.1823 \\
(0.6887)\end{array}$ \\
\hline $\ln U S L$ & $\begin{array}{c}0.6233 \\
(0.9574)\end{array}$ & $\begin{array}{c}0.7605 \\
(0.9648)\end{array}$ & $\begin{array}{c}0.5633 \\
(1.0036)\end{array}$ & $\begin{array}{r}0.7583 \\
(1.0121)\end{array}$ \\
\hline $\operatorname{lnMAQ} * D N O N$ & $\begin{array}{l}0.2200^{\circ *} \\
(0.0658)\end{array}$ & $\begin{array}{l}0.2225^{* *} \\
(0.0661)\end{array}$ & $\begin{array}{l}0.3590^{\circ} \\
(0.0827)\end{array}$ & $\begin{array}{l}0.3757^{* *} \\
(0.0831)\end{array}$ \\
\hline InMAQ*DDUR & $\begin{array}{l}0.4328^{* *} \\
(0.0646)\end{array}$ & $\begin{array}{l}0.4387^{* *} \\
(0.0653)\end{array}$ & $\begin{array}{l}0.5782^{* *} \\
(0.0823)\end{array}$ & $\begin{array}{l}0.6006^{*} \\
(0.0818)\end{array}$ \\
\hline $\begin{array}{l}\text { F-statistic on equality of } \\
\text { coefficients for lnMAQ }\end{array}$ & $16.47^{* *}$ & $16.94^{\circ *}$ & $13.54^{* *}$ & $13.98^{* *}$ \\
\hline Adjusted $\mathrm{R}^{2}$ & 0.9853 & 0.9853 & 0.9846 & 0.9845 \\
\hline Number of Observations & 168 & 168 & 168 & 168 \\
\hline
\end{tabular}

* $\left({ }^{* *}\right)$ Indicates statistical significance at the five-percent (one-percent) level. All regressions include dummy variables for the city-industry and the year. DNON is a dummy variable indicating nondurable-goods industry; DDUR is a dummy variable indicating durable-goods industry. Instruments include the (presumed) exogenous independent variables and the first lag of InMAQ. 

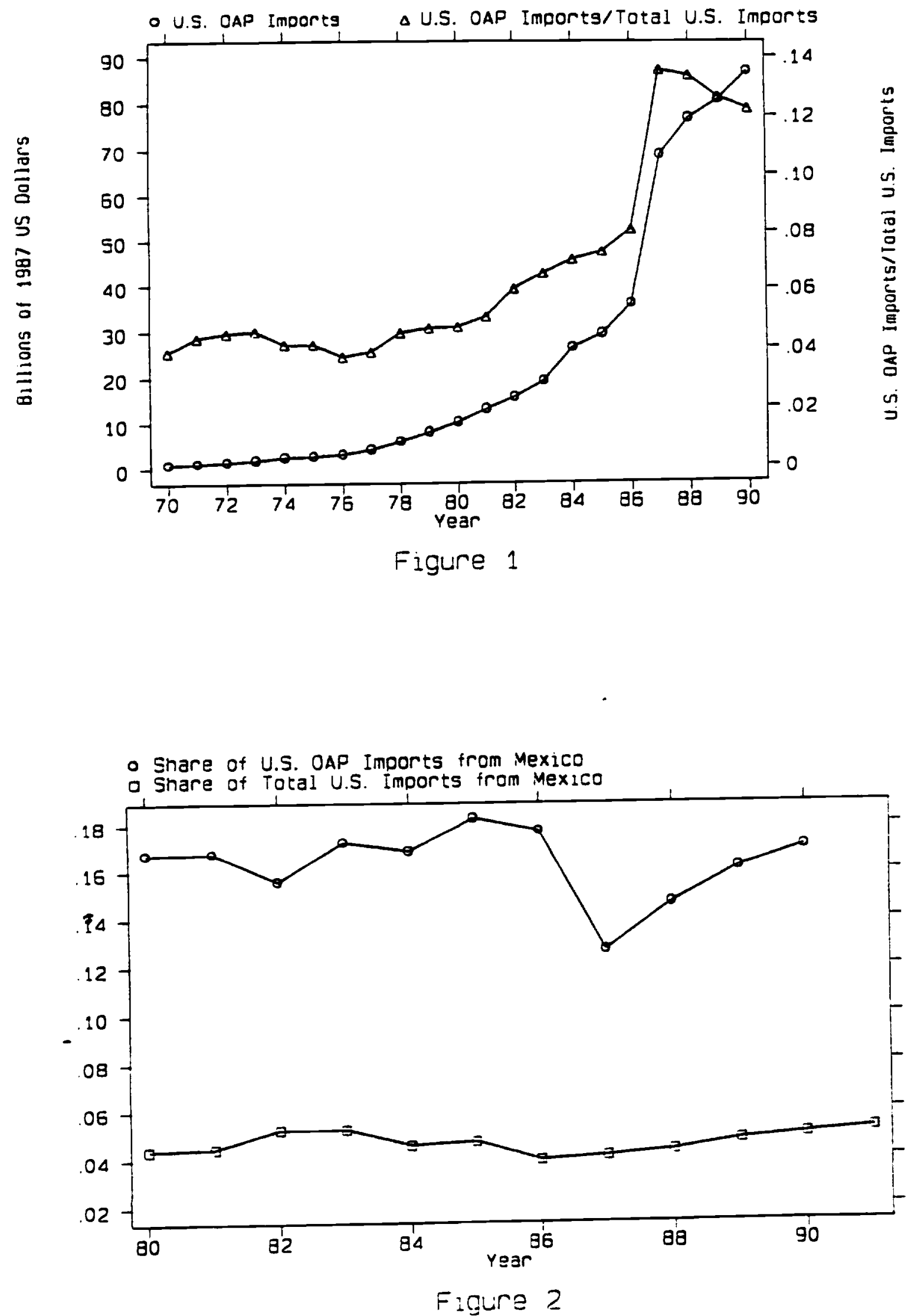